\title{
Paraoxonase Activity in Cirrhotic and Non Alcoholic Steatohepatitis Patients
}

\author{
Mohamed Fathallah M. Hassan ${ }^{1}$, Mohy eldin Abdelfattah ${ }^{2}$, Aziza Ismail ${ }^{3}$, Fathallah M. Hassan ${ }^{4}$ \\ ${ }^{1}$ Faculty of Medicine, Department of Internal Medicine \\ ${ }^{2,3}$ Faculty of Science, Department of Chemistry \\ ${ }^{4}$ Faculty of Medicine, Department of Biochemistry, Suez Canal University, Ismailia, Egypt
}

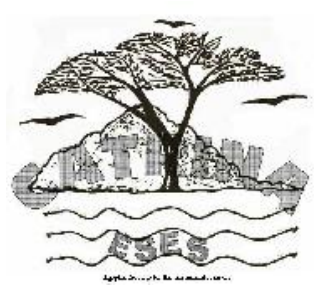

Paraoxonase-1 (PON1) is an esterase and lactonase synthesized by the liver and found in the circulation associated with high-density lipoproteins (HDL). The physiological function of PON1 seems to degrade specific oxidized cholesteryl esters and oxidized phospholipids in lipoproteins and cell membranes. Alterations in circulating PON1 levels have been reported in a variety of diseases involving oxidative stress including chronic liver diseases. The aim of this work has been planned to demonstrate: the PON1 activity in cirrhosis and non alcoholic steatohepatitis (NASH). This study was carried out on 40 Patients from Internal Medicine clinic, Suez Canal University Hospital, divided in two groups; 20 patients suffering from cirrhosis (Cirrhosis group) and 20 patients suffering from NASH (NASH group) in addition to 20 healthy subjects free from any disease as control group. Fasting blood sugar, lipid profile and liver function tests were performed in all groups using colorimetric methods, PON1 activity was measured colorimetri-cally using paraoxon as a substrate and apolipoprotein A1(ApoA1) using nephlometric method. PON1 activity and ApoA1 levels were significantly decreased in cirrhosis and NASH patients compared to controls. Cirrhotic patients demonstrated normal lipid profile compared to their controls except HDL which demonstrated low levels while dyslipidemia was demonstrated in NASH patients. High levels of ALT and AST were demonstrated in the two patients groups with low levels of albumin and high levels of total and direct bilirubin in cirrhotic patients only compared to the controls. PON1 activity was found positively correlated with ApoA1 in the two patients groups while it was found positively correlated with HDL and negatively correlated with LDL in NASH group only. PON1activity and ApoA1were significantly reduced in cirrhosis and NASH patients compared to their controls. Dyslipidemia is associated with patients of NASH. A positive correlation was seen between PON1 activity and Apo A1 in the two discussed diseases.

Key wards: ApoA1, Cirrhosis, Dyslipidemia, Oxidative stress, NASH, PON1.

\section{INTRODUCTION}

PON1 is an enzyme associated with HDL in circulation. It is a liver-derived glycoprotein of 354 amino acids with a molecular mass of $43 \mathrm{k}$ Da (PrimoParmo et al., 1996); a calcium dependant, containing ApoA1 and apo $\mathrm{J}$ (Blatter et al, 1993). Its gene is a member of a larger gene family of PONs, which includes two other expressed proteins (PON2 and PON3), but PON1 is the dominant PON activity in blood (Draganov, 2007). PON1 has the ability to hydrolyze the organophosphate substrate paraoxon that is the toxic metabolite of the insecticide parathion. It could hydrolyze pro inflammatory oxidized lipids which present in oxidized low density lipoprotein (LDL) and ruins their potentially atherogenic characteristics (Watson et al, 1995).

It can hydrolyze homocysteine thiolactones, a metabolite of homocysteine (Jakubowski, 2000) and prevents lipid oxidation: not only of LDL, but also of HDL itself (Costa et al, 2005). This protection is probably related to PON1-hydrolysing activity of some activated phospholipids (Watson et al, 1995) and/or lipid peroxide products. Marsillach et al. (2008) reported that alterations in circulating PON1 concentrations have been reported in a variety of diseases involving oxidative stress.

These include cardiovascular disease, Alzheimer's disease, chronic renal failure, HIV-infection, metabolic syndrome, and chronic liver impairment. These alterations may adversely affect the protective role of HDL against oxidative stress and inflammation in these patients (Marsillach et al, 2010).
Chronic liver diseases are associated with increased oxidative stress, patients with liver cirrhosis had an increased serum concentration of total peroxides (a marker of oxidative stress), monocyte chemoattractant protein-1 (an index of inflammation), and procollagen III peptide (a marker of liver fibrogenesis). All these changes were observed to be strongly associated with a decrease in serum PON1 activity (Marsillach et al, 2010) which demonstrates a peroxidase like activity and acts as antioxidant.

NASH is a form of chronic hepatitis with histological features of alcohol-induced liver disease that occurs in individuals who do not consume significant amounts of alcohol (Alba and Lindor, 2003). The pathogenesis of NASH remains unclear, although two pathways of injury are implicated: increased oxidative stress and lipid peroxidation associated with increased fat deposition in the liver, and tumor necrosis factor endotoxin-mediated injury (Tilg and Diehl, 2000). Female gender, obesity, hyperlipidemia and diabetes mellitus are well-known risk factors of NASH (Alba and Lindor, 2003). Serum PON1 activity is generally considered to vary in response to the consumption of PON1 for the prevention of oxidation (Aviram et al, 1999).

As PON1 exerts a protective effect against oxidative stress, it is logical to find an association between this enzyme and liver impairment. Mackness et al. (1991) investigated the protection against copper-induced LDL oxidation in vitro provided by purified PON1.

They observed that this enzyme prevents the generation of lipoperoxides during the process of LDL 
oxidation. Further studies reported that PON1 protects LDL and HDL from lipid peroxidation by degrading specific oxidized cholesterol esters and phospholipids contained in oxidized lipoproteins (Aviram et al, 1998).

Ferre et al. (2001) observed, in rats with $\mathrm{CCL}_{4}$ induced fibrosis that an inhibition of hepatic PON1 activity was an early biochemical change related to increased lipid peroxidation and liver damage which suggested that PON1 activity may be involved in the defense against free radical production in liver organelles. Many authors reported that PON1 activity decreases in patients with liver cirrhosis (Ferre et al., 2005).

Clinical diagnosis of chronic liver impairment and/or liver fibrosis is currently conducted via the invasive procedure of needle biopsy followed by histological evaluation. This procedure has important defects including a significant mortality rate, sampling error, and subjectivity. Therefore, the development of noninvasive tests for the diagnosis of liver disease and the extent of the disease is an important goal of current research. Ferre et al. (2002) proposed the addition of PON1 measurement as a biomarker of liver impairment. ApoA1 is a $29.0 \mathrm{kDa}$ protein comprising 243 amino acids (Navab et al, 2006) and is encoded by the APOA1 gene (Arinami et al, 1990). It produced in the liver and intestine and secreted as the predominant constituent of nascent HDL particle (Navab et al, 2006). Defects in the gene encoding it are associated with HDL deficiencies (Arinami et al, 1990).

It has a specific role in lipid metabolism, promotes cholesterol efflux from tissues to the liver for excretion, a cofactor for lecithin cholesterolacyl transferase (LCAT) which is responsible for the formation of most plasma cholesteryl esters (Yui et al, 1988) and delivers them to the liver or steroidogenic tissues via cell surface receptors (Pownall and Gotto, 1992), defines the size and shape of HDL, solubilizes its lipid components and helps to clear cholesterol from arteries (Dastani et al, 2006). The inhibition of LDL oxidation by HDL is due to associated proteins of HDL particle; PON1, LCAT and ApoA1. The combination of these proteins significantly enhanced the length of time LDL was protected from oxidation (Hine et al, 2012). The aim of this work has been planned to demonstrate PON1 activity in diseases associated with dyslipidemia as $\mathrm{NASH}$ and cirrhosis.

\section{MATERIAL AND METHODS}

This study was carried out on 40 patients from Internal Medicine clinic, Suez Canal University Hospital, divided into two groups, cirrhosis group and NASH group, each of them consists of 20 patients, in addition to 20 healthy subjects from the outpatient clinic came to make their check up and were free from any disease. All patients were diagnosed by the faculty members of the mentioned department, their age ranged from 40 to 60 years old. All patients and healthy subjects were subjected to full history taking including age, sex, height, weight and biochemical investigations. Five $\mathrm{ml}$ of fasting blood samples were collected from each of them. Sera were separated by centrifugation of the collected blood at $3000 \mathrm{rpm} / \mathrm{min}$ for 10 minutes and stored at $-20^{\circ} \mathrm{C}$ till the time of their measurements for the following biochemical parameters: fasting blood sugar according to the method described by Burrin and Price 1985; lipid profile including cholesterol (Allain et al., 1974), triglycerides (Fossati and Prencipe, 1982), HDL (Burstein et al., 1970) and LDL (Rifai et al., 2001). Liver function tests were also carried on the same samples including ALT and AST (Bergmeyer et al., 1986), albumin (Doumas and Peters, 1971), total and direct bilirubin (Balistreri and Shaw, 1987).

\section{ASSAY Of SERUM PARAoxonase ACtivity}

Serum paraoxonase activity was determined according to La Du and Eckerson, 1984 using paraoxon (Sigma) as a substrate and measuring the increase in the absorbance at wavelength $405 \mathrm{~nm}$ due to formation of 4-nitrophenol by the effect of paraoxonase on paraoxon by adding $50 \mu 1$ sample serum to $1 \mathrm{ml}$ Tris/HCL buffer (100mmol/L, PH 8.0) containing $2 \mathrm{mmol} / \mathrm{L} \mathrm{CaCl}_{2}$ and $5.5 \mathrm{mmol} / \mathrm{L}$ paraoxon (freshly prepared). The rate of generation of 4-nitrophenol was determined / minute by using of UV-visible photometer at $25^{\circ} \mathrm{C}$ Enzymatic activity was calculated from the molar extinction coefficient $17100 \mathrm{~m}-1 \mathrm{~cm}-1$ using $1 \mathrm{~cm}$ light path cuvette according to the following equation:

\section{PON1 activity $=\Delta A /$ minute $\times F$}

Where $\mathrm{F}=$ factor $=(T V / S V) / 0.0171$ However $\mathrm{TV}=$ Total volume in $\mu \mathrm{l}, \mathrm{SV}=$ sample volume in $\mu 1,0.0171=$ micromolar extinction coefficient

\section{DETERMINATION OF APOLIPOPROTEIN A1 USING BINDING SITE GROUP PRODUCT}

ApoA1 (soluble antigen) is determined using the method described by (Rifai, 1986) which involves the formation of insoluble complexes by adding specific antiserum. When light is passed through the suspension formed, a portion of light is scattered and detected by a photodiode. The amount of light scattered is directly proportional to the specific protein concentration (ApoA1) in the test sample. Concentrations are automatically calculated by reference to a calibration curve stored within the instrument (Minineph Plus instrument).

\section{Procedure}

One Minineph cuvette was prepared for each sample to be assayed. A stirring bar was placed in each cuvette and 20 ul of diluted sample (diluted 1:30 by sample diluent Supplied) were added to the bottom of each cuvette. The cuvette was placed in the chamber of the Minineph Instrument after switching it on and preparing it for measurement, the cuvette was detected automatically. 
Four hundreds of minineph apolipoprotein -A1 buffer and $40 \mathrm{ul}$ of minineph apolipoprotein-A1 antiserum were added to the previous tube then the result was displayed automatically in $\mathrm{g} / \mathrm{L}$.

\section{Demographic Data}

\section{RESULTS}

The demographic data of each studied group are shown in table (1).

Table (1): Demographic Data of Each Studied Group.

\begin{tabular}{cccc}
\hline \hline Variable & $\begin{array}{c}\text { Cirrhosis } \\
\text { Group }\end{array}$ & $\begin{array}{c}\text { NASH } \\
\text { Group }\end{array}$ & Control \\
\hline Gender & & 3 & 8 \\
$\mathrm{~F}$ & 2 & 17 & 12 \\
$\mathrm{M}$ & 18 & $90 \pm 5.77$ & $71.625 \pm 1$. \\
Weight $(\mathrm{k}$ & $79.5 \pm 0.499$ & 546 \\
$\mathrm{~g}) \mathrm{F}$ & & & $77.25 \pm 0.8$ \\
$\mathrm{M}$ & $79 \pm 1.063$ & $92.941 \pm 4.6$ & 56 \\
$\mathrm{~T}$ & $79.05 \pm 1$ & $92.5 \pm 2.312$ & $75 \pm 1.21$ \\
Height(m & $1.655 \pm 0.02$ & $1.633 \pm 0.01$ & $1.655 \pm 0.0$ \\
) F & 5 & 6 & 08 \\
$\mathrm{M}$ & $1.678 \pm 0.00$ & $1.688 \pm 0.04$ & $1.678 \pm 0.0$ \\
& 8 & & 12 \\
$\mathrm{~T}$ & $1.676 \pm 0.01$ & $1.679 \pm 0.01$ & $1.669 \pm 0.0$ \\
$\mathrm{BMI}$ & $29.039 \pm 0.6$ & $33.757 \pm 2.2$ & $26.273 \pm 0$. \\
$(\mathrm{kg} / \mathrm{m} 2) \mathrm{F}$ & 93 & 33 & 566 \\
$\mathrm{M}$ & $28.045 \pm 0.3$ & $32.747 \pm 2.0$ & $27.426 \pm 0$. \\
$\mathrm{P} *$ & 26 & 29 & 316 \\
$\mathrm{~T}$ & $>0.05$ & $>0.05$ & \\
$\mathrm{P} * *$ & $28.14 \pm 0.35$ & $32.898 \pm 0.7$ & $26.97 \pm 0.3$ \\
\hline \hline $\mathrm{Al}$ & $>0.05$ & 70.05 & 3 \\
\hline
\end{tabular}

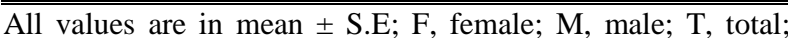
BMI, Body mass index

$\mathrm{NASH}$, Non alcoholic steatohepatitis; $\mathrm{p}^{*<0.05}$ is statistically significant comparing $\mathrm{F}$ against $\mathrm{M}$

$\mathrm{p}^{* *<0.05}$ is statistically significant comparing to control group.

As shown in table (1) BMI of cirrhosis group is significantly different from the control group $(\mathrm{p}=0.107)$ while it was found significantly higher in NASH group compared to the control group $(\mathrm{p}=0.000)$. Liu et al, (2010) reported that $17 \%$ of liver cirrhosis is attributable to increased body weight in middle-aged women in the UK. Barclay (2011) reported that obesity accelerates the progression of cirrhosis; Patients who are overweight or obese are at greater risk of accelerating the progression of cirrhosis.

Our results of BMI of NASH group came in agreement with the findings obtained by Capristo et al. (2005), Fierbinteanu - Braticevici et al. (2011), Samy and Hassanian (2011) and Hashemi et al. (2012). Female and male BMI showed no difference when compared to each other in the two groups.
Biochemical and Clinical Data of the Studied Groups

The results in table (2) demonstrated the biochemical characteristics of cirrhosis, NASH groups and healthy subjects. These biochemical features include FBS, Cholesterol, TG, HDL, LDL, ALT, AST, Albumin, D. Bilirubin and T. Bilirubin. Cirrhotic patients demonstrated normal lipid profile compared to the control group except for HDL which was significantly lower compared to their respective controls $(\mathrm{p}<0.05)$ while in NASH group cholesterol, TG and LDL were found significantly higher compared to their respective controls $(\mathrm{p}<0.05)$. In addition to decreased levels of HDL which were significantly lowered compared to their respective controls $(\mathrm{p}<0.05)$. Ghadir et al. (2010) reported that, in patients with cirrhosis, there was a significant decrease in serum triglyceride, total, LDL and HDL cholesterol levels compared to the control group which came inpartly in agreement with the present results. Halsted (2004) reported that there is prominent decline in plasma cholesterol and triglyceride levels in patients with severe hepatitis and hepatic failure because of reduction of lipoprotein biosynthesis. For reduced liver biosynthesis capacity, low levels of TG and cholesterol is usually observed in chronic liver diseases.

The same results were obtained in a study by Siagris et al. (2006). In NASH group the results obtained from the present study came in agreement with results obtained by Samy and Hassanian (2011); Hashemi et al. (2012) and Albano et al. (2012) who reported that dyslipidaemia are associated with NASH and may have a role in its pathogenesis. These metabolic disorders lead to increased circulating levels of free unsaturated fatty acids with enhanced concentration in the liver leading to hepatic steatosis, which is considered the first hit to the liver (Pagano et al, 2002 and Schiff et al, 2007). Duvnjak et al. (2007) reported that fatty liver has been documented in up to 10 to 15 percent of normal individuals and 70 to 80 percent of obese individuals. Fat cells are the only specialized cells to store triglycerides without harm for themselves. All other cell types including liver cells may store only a limited quantity of fat for their current fuel needs without injury to their condition. Excess of fat in liver cells results in lipotoxicity (lipid-induced cellular injury) and sometime later it eventually results in lipoapoptosis of liver cells. Excess hepatic triglyceride accumulation is associated with various medications, nutritional factors, and multiple genetic defects in energy metabolism. However, the most common disorder which results in hepatic steatosis is the metabolic syndrome (David et al, 2002).

Both cirrhosis and NASH patients demonstrated high levels of liver function tests. The biochemical feature of the two groups showed increased disturbances in the levels of the liver function tests including ALT, AST, albumin and bilirubin (total and direct) (table 2). The differences between the two groups were found in the levels of bilirubin (total and direct) which were 
significantly higher in cirrhotic group than those of NASH and healthy subjects. Albumin was lower in cirrhotic group than those of NASH and healthy subjects (table 2). ALT and AST were found significan- tly higher in patients of cirrhosis group $(\mathrm{p}<0.05)$. Albumin was significantly lowered $(\mathrm{p}<0.05)$ while direct and total bilirubin were found significantly higher $(\mathrm{p}<0.05)$ compared to the controls.

Table (2): Biochemical and Clinical Data of Each Studied Group.

\begin{tabular}{|c|c|c|c|c|c|}
\hline & $\mathrm{DM}$ & & Lipid Profile & & \\
\hline & $\mathrm{FBS}, \mathrm{mmol} / \mathrm{L}$ & Chol,mmol/L & $\mathrm{TG}, \mathrm{mmol} / \mathrm{L}$ & HDL,mmol/L & $\mathrm{LDL}, \mathrm{mmol} / \mathrm{L}$ \\
\hline Cirrhosis & $5.01 \pm 0.126$ & $3.597 \pm 0.127$ & $1.113 \pm 0.056$ & $0.936 \pm 0.046 *$ & $2.068 \pm 0.151$ \\
\hline NASH & $5.04 \pm 0.128$ & $5.945 \pm 0.25 *$ & $2.379 \pm 0.279 *$ & $1.069 \pm 0.031 *$ & $3.85 \pm 0.174 *$ \\
\hline \multirow[t]{3}{*}{ Control } & $5.18 \pm 0.08$ & $4.19 \pm 0.07$ & $1.038 \pm 0.03$ & $1.49 \pm 0.046$ & $2.219 \pm 0.094$ \\
\hline & \multicolumn{5}{|c|}{ Liver Function Tests } \\
\hline & ALT, U/L & AST, U/L & Alb,g/L & D.B, $\mu \mathrm{mol} / \mathrm{L}$ & T.B, $\mu \mathrm{mol} / \mathrm{L}$ \\
\hline Cirrhosis & $61 \pm 3.37 *$ & $84 \pm 5.54 *$ & $27.29 \pm 0.45^{*}$ & $9.422 \pm 0.901 *$ & $32.82 \pm 2.51 *$ \\
\hline NASH & $87.2 \pm 6.55^{*}$ & $61.15 \pm 4.307 *$ & $40.14 \pm 3.177 *$ & $1.577 \pm 0.995$ & $12.492 \pm 3.65$ \\
\hline Control & $16.75 \pm 0.833$ & $13.9 \pm 0.784$ & $42.41 \pm 1.077$ & $0.76 \pm 0.104$ & $10.82 \pm 0.612$ \\
\hline
\end{tabular}

FBS, fasting blood sugar; chol, cholesterol ; TG, triglycerides; HDL, high density lipoprotein; LDL, low density lipoprotein; ALT, alanine amino transferase; AST, aspartate aminotransferase; PON1, paraoxonase 1; ApoA1, apolipoprotein A1; NASH, non alcoholic steatohepatitis.

In NASH group ALT and AST were found significantly higher $(\mathrm{p}<0.05)$ and albumin was significantly decreased $(\mathrm{p}<0.05)$ compared to the controls while there was no difference seen in total and direct bilirubin compared to the controls.

Several studies have shown that AST/ ALT ratio is typically $<1$, but with progression to cirrhosis the ratio often increases to $>1$, the specificity of a ratio $>1$, for cirrhosis is $75-100 \%$, with a sensitivity of $32-83 \%$ (Bonacini et al, 1997 and Sheth et al, 1998), these findings came in consistence with our results where the ratio of AST/ALT was $>1$ in all the cases of cirrhotic patients. This appears to be attributable to a reduction of ALT production in damaged liver (Schmidt and Schmidt, 1990) while it was $<1$ in NASH patients.

Cirrhosis refers to a progressive, diffuse, fibrosing and nodular condition that disrupts the entire normal architecture of the liver (Friedman and Schiano, 2004; Crawford, 2005). It is a chronic degenerative disease in which normal liver cells are damaged and are then replaced by scar tissue, it is most often caused by alcoholism, hepatitis B, hepatitis $\mathrm{C}$ and other causes include gallbladder diseases, too much iron in the liver and autoimmune hepatitis. The progression of liver injury to cirrhosis may occur over weeks to years (Wolf, 2012).

Patients with liver cirrhosis have developed permanent damage to their liver, causing portions of the liver to be replaced with scar tissue. When this happens, the liver's ability to produce proteins (such as albumin) becomes impaired, causes a significant drop in serum albumin levels which is used as a marker for the severity as part of the Child-Pugh classification of cirrhosis. These findings came in consistence with the present results. Our results came in agreement with the results obtained by Kedage et al. (2010), Marsillach et al. (2010), who reported that relative to the control group, the patients with cirrhosis had a significant increase in serum aminotransferases together with a decrease in albumin and HDL-cholesterol concentrations.
NASH represents the most severe histologic form of nonalcoholic fatty liver disease (NAFLD), which is defined by fat accumulation in the liver exceeding 5\% of its weight. The disease can remain asymptomatic for years, or can progress to cirrhosis and hepatocellular carcinoma (WGO, 2012).

The major feature in NASH is fat in the liver, along with inflammation and damage.

Many patients with NASH have elevated blood lipids, such as cholesterol and triglycerides (NIDDC, 2006). In chronic liver diseases, oxidative stress influences the pathophysiological changes leading to liver cirrhosis and to hepatocellular carcinoma. Since PON1 exerts a protective effect against oxidative stress, it is logical to find an association between this enzyme and liver impairment. Table (3) demonstrates lipid profile, PON1 activity and ApoAlin cirrhosis and NASH groups.

Table (3): PON1activity and ApoA1 in Cirrhotic and NASH Group.

\begin{tabular}{lll}
\hline \hline & $\begin{array}{l}\text { PON1 } \\
\text { U/L }\end{array}$ & $\begin{array}{l}\text { ApoA1 } \\
\mathrm{g} / \mathrm{L}\end{array}$ \\
\hline Control & $48.979 \pm 2.2$ & $1.83 \pm 1.71$ \\
Cirrhosis & $9.756 \pm 0.72^{*}$ & $0.57 \pm 0.03^{*}$ \\
NASH & $23.75 \pm 1.197^{*}$ & $1.21 \pm 0.4^{*}$ \\
\hline \hline
\end{tabular}

Data demonstrated as mean $\pm \mathrm{SE}, * \mathrm{p}<0.05$ is significant comparing to controlChol, cholesterol; TG, triglycerides; LDL, low density lipoprotein; HDL, high density lipoprotein; PON1, paraoxonase -1; ApoA-1, apolipoprotein A-1.

As shown in table (3) PON1 activity and ApoA1 levels show significant reduction in cirrhotic group compared to their respective controls $(\mathrm{p}<0.05)$. Our results came in agreement with the results obtained by Kedage et al. (2010), Marsillach et al. (2007and 2010) who reported that relative to the control group, the 
patients with cirrhosis showed a highly decrease in serum PON1 activity and ApoAlconcentration. These results came in agreement with the results obtained by Ferre et al. (2006) and Geetha et al. (2007). Two mechanisms may be suggested to explain the decrease of serum PON1 activity in patients with chronic liver diseases; It may be due to increased concentration of total peroxides in serum of those patients and it has been previously reported that PON1 is inactivated after hydrolyzing lipid peroxides, a second possible mechanism may be related to the fact that alterations in HDL structure and composition can affect PON1 activity (James and Deakin, 2004). Ferré (2005) reported that a decrease in PON1 activity suggest an active role of PON1 in the regulation of oxidative stress, fibrosis and hepatic cell apoptosis in chronic liver diseases. Results obtained from the present study demonstrated a positive correlation between PON1andApoA1 in the cirrhotic patients as shown in figure (1).

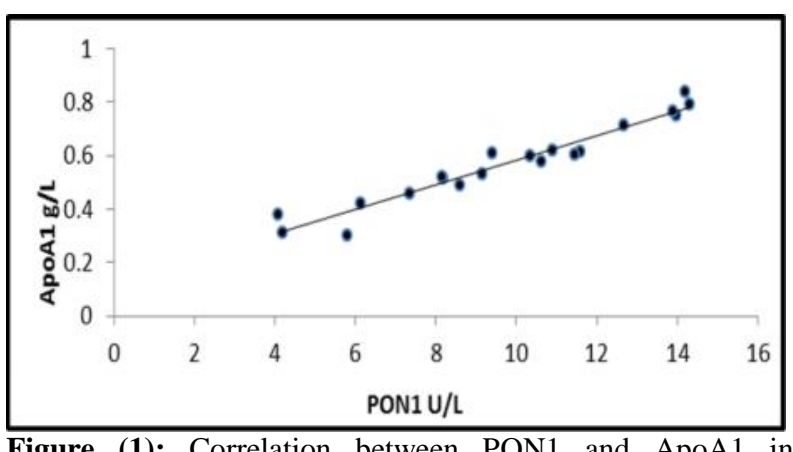

Figure (1): Correlation between PON1 and ApoA1 in cirrhotic group

$\mathrm{r}=0.965, \mathrm{p}<0.001$, ApoA1, apolipoprotein A1, PON1, paraoxonase 1 .

Results obtained by Prakash et al, (2007), Samy and Hassanian (2011) and Hashemi et al, (2012) demonstrated significant elevation of ALT and AST activities in addition to significant decrease in PON1 activity which came in agreement with the results of the present study. The decrease in serum PON activity in NASH patients might have resulted from increased inactivation of PON1 according to increased generation of reactive oxygen species in NASH (Aviram et al, 1999).

The liver responds to a pro-oxidant by increasing the synthesis of protective antioxidants enzymes, while with disease progression, the liver's capacity to synthesize antioxidant enzymes may be seriously affected. The increased products of lipid peroxidation in patients with NAFLD create and amplify oxidative stress and disturb the balance between antioxidants and pro-oxidants. In turn, oxidative stress can cause liver injury and is considered the second hit to the liver leading to the development of NASH. Decrease in PON1 activity is associated with altered lipoprotein metabolism with a significant decrease in HDL-C and increase in LDL-C levels, which was found in the present study. PON1 activity showed a significant positive correlation with HDL levels as shown in figure (2), and showed a significant negative correlation with LDL as shown in figure (3), which are consistent with the results obtained by Samy and Hassanian (2011).There was a positive correlation between PON1 and ApoA1 as shown in figure (4).

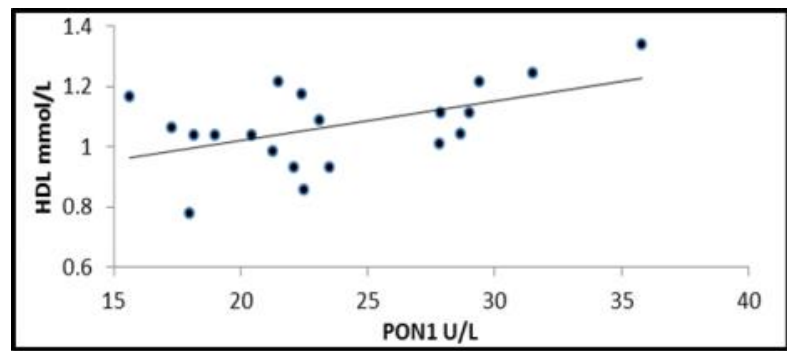

Figure (2): Correlation between HDL and PON1 activity in NASH group.

$\mathrm{r}=0.512, \mathrm{p}=0.022$, PON1, paraoxonase A1, HDL, high density lipoprotein.

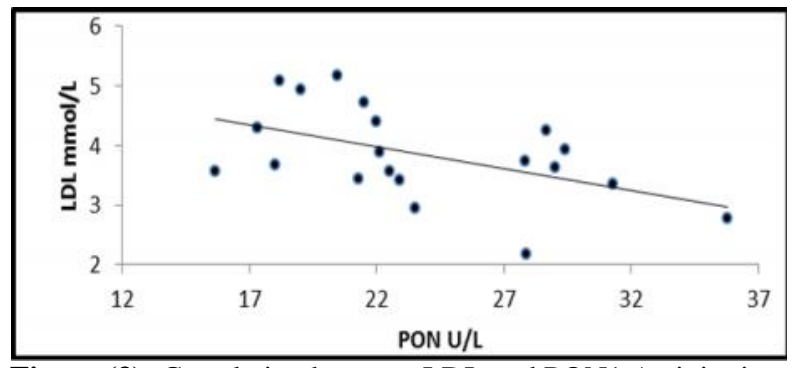

Figure (3): Correlation between LDL and PON1 Activity in NASH group

$\mathrm{r}=-0.505, \mathrm{p}=-0.023, \mathrm{PON} 1$, paraoxonase $1, \mathrm{LDL}$, low densitylipoprotein.

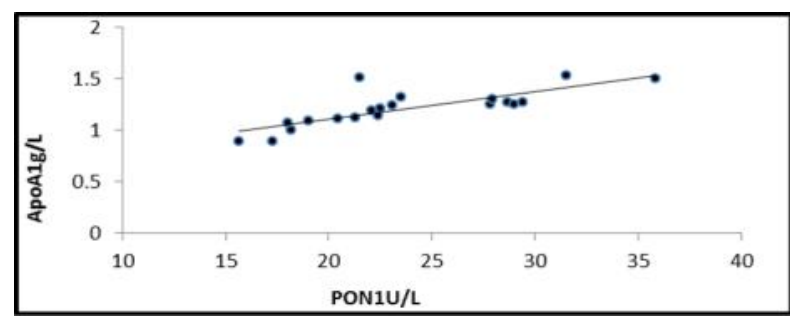

Figure (4): Correlation between PON1Activity and ApoA1 in NASH group.

$\mathrm{r}=0.792, \quad \mathrm{p}<0.001, \quad$ PON1, paraoxonase 1, ApoA1, apolipoprotein A1.

Results obtained from the present study of NASH demonstrated obesity, dyslipidemia, reduced PON1 activity and reduced ApoA1 levels when compared to their respective controls.

Obesity and dyslipidemia are considered as important risk factors for the development of hepatic steatosis and reduced serum PON1 activity reflects increased oxidative damage in patients with NASH. In addition ApoA1 promotes cholesterol efflux from tissues to the liver for excretion. It is a cofactor for LCAT which is responsible for the formation of most plasma cholesteryl esters. The combination of PON1, 
LCAT and Apo A1 significantly enhance the length of time LDL would be protected from oxidation due to the ability of PON1 to prevent the oxidative inactivation of LCAT. Any defect of these proteins affect on the reverse cholesterol transport pathway and increasing of oxidative stress. Any defect of these proteins affects the reverse cholesterol transport pathway and increases oxidative stress.

In conclusion, it was found from this study that PON1 enzyme activity and ApoA1were significantly reduced in cirrhosis and NASH groups. In addition dyslipidemia is associated with patients of NASH. A positive correlation was seen between PON1 activity and ApoA1 in the two discussed diseases.

Further research is recommended in large populations; study the genetic polymorphism distribution to achieve a compact overview that could explain the variability in PON1 activity and its relationship with the other factors that associate the disease and its complications. In addition further controlled studies on the role of atorvastatin and antioxidants in the prevention of the progression of liver steatosis are required.

\section{REFERENCES}

ALBA, L. M. AND K. LINDOR. 2003. Review article: non-alcoholic fatty liver disease. Alimentary Pharmacolology and Therapeutics 17: 977-86.

ALBANO, E., E. MOTTARAN; M. VIDALI, E. REALE, SAKSENA, S. G. OCCHINO, A. D. BURT, AND C. P. DAY. 2005. Immune response towards lipid peroxidation products as a predictor of progression of non-alcoholic fatty liver disease to advanced fibrosis. Gut 54: 987-993.

Allain, C; L. S. POON; C. S. CHAN, W, RICHMOND, AND P. C. FU. 1974. Enzymatic determination of total cholesterol. Clinical Chemistry 20:(4):470- 475.

ARINAMI, T., T. HIRANO, K. KOBAYASHI, Y. YAMANOUCHI, HAMAGUCHI, AND H. ASSIGN. 1990. Assignment of the apolipoprotein A-I gene to $11 q 23$ based on relp in a case with a partial deletion of chromosome 11, del (11) (q23.3-qter). Human Genetics 85 (1): 39-40.

AVIRAM, M., M. ROSENBALT, S. BILLECKE, J. EROGUL. R. SORENSON. CH. L. BISGAIR, R.S. NEWTON, AND B. LA DU. 1999. Human serum paraoxonase (PON 1) is inactivated by oxidized low density lipoprotein and preserved by antioxidants. Free Radical Biology and Medicine 26: 892-904.

AVIRAM, M, M, ROSENBLAT, C. L. BISGAIER, R. S. NEWTON, S. L. PRIMO-PARMO, AND B. N. LA DU. 1998. Paraoxonase inhibits high density lipoprotein (HDL) oxidation and preserves its functions. a possible peroxidative role for paraoxonase. Journal of Clinical Investigation 101(8): 1581-1590.

BALISTRERI, W. F., AND L. M. SHAW. 1987: Liver function. In: Tietz NW, ed. Fundamentals of Clinical
Chemistry. 3rd ed. Philadelphia, PA: WB Saunders Co, 729-761.

Barclay, L. 2011. Obesity Linked to Risk for Decompensation of Cirrhosis. Hepatology 54:555561.

BERGMEYER, H. U., M. HORDER, AND R. REJ. 1986. Approved recommendation on IFCC methods for the measurement of catalytic concentration of enzymes part 3. IFCC method for alanine amino transferase journal of clinical chemistry and clinical biochemistry 24(7): 481-4195.

BLATTER, M. C., R. W. JAMES, S. MESSMER, F. BARJA, AND D. POMETTA. 1993. Identification of a distinct human high-density lipoprotein subspecies defined by a lipoprotein-associated protein, K-45. identity of K-45 with paraoxonase. European Journal of Biochemistry 211(3): 871-879.

BONACINI, M., G. HADI, S. GOVINDARAJAN, AND K. L. LINDSAY. 1997. Utility of a discriminant score for diagnosing advanced fibrosis or cirrhosis in patients with chronic hepatitis $\mathrm{C}$ virus infection. American Journal of Gastroenterol 92 :1302 -1304.

Burrin, J. M., AND C. P. Price. 1985. Measurment of blood glucose. Annals of Clinical Biochemistry 22: 327-342.

Burstein, M., H. R. Scholnick, AND R. Morfin. 1970. Rapid method for isolation of lipoproteins from human serum by preciciptation with polyanions. Journal of lipid research 11(6):583- 595.

CAPRISTO, E., L. MIELE, A. FORGIONE, V. VERO, S. FARNETTI, G. MINGRONE, A. V. GRECO, G. GASBARRINI, AND A. GRIECO. 2005. Nutritional aspects in patients with non-alcoholic steatohepatitis (NASH). European review for medical and Pharmacological Sciences 9(5): 265-268.

COSTA, L. G., A. VITAlONE, T. B. COLE, AND C. E. FURLONG. 2005. Modulation of paraoxonase (PON1) activity. Biochemical Pharmacology 69(4): 541-550.

CRAWFORD, J. M. 2005. Liver and biliary tract. In Robbins and Cotran Pathological Basis of Disease. (Kumar, V., A. K. Abbas, N. Fausto. eds.). $7^{\text {th }}$ edn, pp. 877-938. Elsevier Saunders, New York, NY.

DASTANI, Z., C. DANGOISSE, B. BOUCHER, K. DESBIENS, L. KRIMBOUM, R. DUFOUR, R. A. HEGELE, P. PAJUKANTA, J. C. ENGERT, J. GENEST, AND M. MARCIL. 2006. A novel nonsense apolipoprotein A-I mutation (apoA$\mathrm{I}(\mathrm{E} 136 \mathrm{X})$ ) causes low HDL cholesterol in French Canadians. Atherosclerosis 185 (1): 127-136.

SHAFRITZ, D. A., AND D. D. MARIANA. 2002. Liver Stem/Progenitor Cells and their Transplantation: from Fantasy to Reality as We Enter the New Millennium. Einstein Quarterly Journal of Biology and Medicine. 19(1):20-32.

DOUMAS, B. T., W. A. WATSON, AND H. G. BIGGS. 1971. Albumin standard and the measurement of serum albumin with bromocresol green. 
Clinica Chemica Acta 31: 87-96.

DRAGANOV, D. I. 2007. Human PON3, Effects Beyond the HDL: Clues from Human PON3 Transgenic Mice. Circulation Research 100: 1104 1105.

DUVNJAK, M., I. LEROTIC, N. BARSIC, V. TOMASIĆ, J. L. VIROVIĆ, AND V. VELAGIĆ. 2007. Pathogenesis and management issues for nonalcoholic fatty liver disease. World Journal of Gastroenterology 13(34): 4539-4550.

FERRE, N., J. CAMPS, M. CABRE, A. PAUL, AND J. JOVEN. 2001. Hepatic paraoxonase activity alterations and free radical production in rats with experimental cirrhosis. Metabolism 50 (9): 997-1000.

FERRE, N., J. CAMPS, E. PRATS, E. VILELLA, A. PAUL, L. FIGUERA, AND J. JOVEN. 2002. Serum paraoxonase activity: a new additional test for the improved evaluation of chronic liver damage. Clininical Chemistry 48: 261-268.

FERRE, N., J. MARSILLACH, J. CAMPS, A. RULL, B. COLL, M. TOUS, AND J. JOVEN. 2005. Genetic association of paraoxonase-1 polymorphisms and chronic hepatitis $\mathrm{C}$ virus infection.Clinica chimica acta, 361(1): 206-210.

FERRE, N., J. MARSILLACH, J. CAMPS, B. MACKNESS, M. MACKNESS, F. RIU, B. COLL M. TOUS, AND J. JOVEN. 2006. Paraoxonase-1 is associated with oxidative stress, fibrosis and FAS expression in chronic liver diseases. Journal of Hepatology 45(1): 51-59.

FIERBINTEANU-BRATICEVICI, C., C. BAICUS, L. TRIBUS, AND R. PAPACOCEA. 2011. Predictive Factors for nonalcoholic Steatohepatitis (NASH) in Patients with nonalcoholic Fatty Liver Disease (NAFLD). Journal of Gastrointestinal and Liver Diseases 20(2):153-159.

FOSSATI, P., AND L. PRENCIPE. 1982. Serum triglycerides determined colorimitically with an enzyme that produces hydrogen peroxide Clinical Chemistry 28(10): 2077-2080.

FRIEDMAN, S., AND T. SCHIANO. 2004. Cirrhosis and its sequelae. In: Goldman L, Ausiello D, eds.Cecil Textbook of Medicine. 22nd ed. Philadelphia, Pa: Saunders, 936-944.

GEETHA, A., M. D. P. LAKSHMI, S. A JEYACHRISTY, AND R. SURENDRAN. 2007. Level of oxidative stress in the red blood cells of patients with liver cirrhosis. Indian Journal of Medical Research 126(3): 204-210.

GHADIR, M. R., A. A. RIAHIN, A. HAVASPOUR, M. NOORANIPOUR, AND A. A. HABIBINEJAD. 2010. The relationship between lipid profile and severity of liver damage in cirrhotic patients. Hepatitis Monthly 10(4): 285-288.

HASHEMI, M., A. BAHARI, N. HASHEMZEHI, A. MOAZENI-ROODI, S. SHAFIEIPOUR, A. BAKHSHIPOUR AND S. GHAVAMI. 2012. Serum paraoxonase and arylesterase activities in Iranian patients with nonalcoholic fatty liver disease. Pathophysiology 19: 115-119.

HASTED, C. H. 2004. Nutrition and alcoholic liver disease. Seminars in Liver Disease 24(3):289-304.

HINE, D., B. MACKNESS, AND M. MACKNESS. 2012. Coincubation of PON1, APO A1, and LCAT increases the time HDL is able to prevent LDL oxidation. IUBMB Life 64 (2):157-161.

JAKUBOWSKI, H. 2000. Homocysteine thiolactone: Metabolic origin and protein homocysteinylation in humans. Journal of Nutrition 130:377S-381S.

JAMES, R. W., AND S. P. DEAKIN. 2004. The importance of high-density lipoproteins for paraoxonase-1 secretion, stability, and activity. Free Radical Biology and Medicine 37:1986-1994.

KEDAGE, V., M. S. MUTTIGI, M. S. SHETTY, R. SUVARNA, S. S. RAO, C. JOSHI, AND M. PRAKASH. 2010. Serum Paraoxonase 1 Activiy Status in Pateints with Liver Disorders. Saudi Journal of Gastroentrology 16 (2):79-83.

LA DU, B. N. AND H. W. ECKERSON. 1984. The polymorphic paraoxonase/arylesterase isozymes of human serum. Federation Proceedings. 43(8): 23382341.

LIU, B., A. BALKWILL, G. REEVES, AND V. BERAL. 2010. Body mass index and risk of liver cirrhosis in middle aged UK women: prospective study. British Medical Journal 340-912.

MACKNESS, M. I., S. ARROL, AND P. N. DURRINGTON. 1991. Paraoxonase prevents accumulation of lipoperoxides in low-density lipoprotein. FEBS Letters 286 (1-2): 152-154.

MARSILLACH, J., G. ARAGONÈS, B. MACKNESS, M. MACHNESS, A. RULL, R. BELTRÁN-DEBÓN, J. PEDRO-BOTET, C. ALONSO-VILLAVERDE, J. JOVEN, AND J. CAMPS. 2010. Decreased paraoxonase-1 activity is associated with alterations of high-density lipoprotein particles in chronic liver impairment Lipids in Health and Disease 9: 46.

MARSILLACH, J., N. FERRE, M. C. VILA, A. LLIGOÑA, B. MACKNESS, M. MACKNESS, R. DEULOFEU, R. SOLÁ, A. PARÉS, J. PEDROBOTET, J. JOVEN, J. CABALLERIA, AND J. CAMPS. 2007. Serum paraoxonase-1 in chronic alcoholics: relationship with liver disease. Clinical Biochemistry 40(9-10): 645-650.

MARSILLACH, J. S. PARRA, N. FERRÉ, B. COLL, C. ALONSO-VILLAVERDE, J. JOVEN, AND J. CAMPS. 2008. Paraoxonase-1 in chronic liver diseases, neuro-logical diseases and HIV infection.The Paraoxonases: Their Role in Disease Development and Xenobiotic Metabolism. Springer Netherlands, 6: 187-198.

NATIONAL DIGESTIVE DISEASES INFORMATION CLEARINGHOUSE (NDDIC). 2006. Nonalcoholic Steatohepatitis. NIH Publication, No. 074921.

NAVAB, M., G. M. ANANTHARAMAIAH, S. T. 
REDDY, AND A. M. FOGELMAN. 2006. Apolipoprotein A-I mimetic peptides and their role in atherosclerosis prevention. Nature Reviews Cardiology 3: 540-547.

PAGANO, G., G. PACINI, G. MUSSO, R. GAMBINO, F. MECCA, N. DEPETRIS, M. CASSADER, E. DAVID, P. CAVALLO-PERIN, AND M. RIZZETTO. 2002. Nonalcoholic steatohepatitis, insulin resistance and metabolic syndrome: further evidence for an etiologic association. Hepatology 35 (2): 367372.

POWNALL, H. J., AND A. M. GOTTO. 1992. Human plasma apolipoproteins in biology and medicine. In: Rosseneu M, ed. Structure and function of apolipoproteins. Boca Raton: CRC Press. pp 1-32.

PRAKASH, M., J. K. SHETTY, S. TRIPATHY, M. VERMA, S. VASUDEV, AND B. V. BHANDARY. 2007. Serum paraoxonase in alcohol abusers associated with alcoholic liver disease. Clinica Chimica Acta 378 (1-2): 232-234.

PRIMO-PARMO, S., R. C. SORENSON, J. TEIBER, AND B. N. LA DU. 1996. The human serum paraoxonase /arylesterase gene (PON1) is one member of a multige family. Genomics 33(3): 498-507.

REFAI, N. 1986. Lipoproteins and apolipoproteins. composition, metabolism and association with coronary heart disease. Archives of Patholology and Laboratory Medicine110(8): 694-701.

REFAI, N., P. S. BACHORIK, AND J. J. ALBERTS. 1999. Lipids, lipoproteins and apolipoproteins. In: Burtis CA, Ashwood ER (eds). Tietz - textbook of clinical chemistry. 3rd ed. Philadelphia: Saunders, p. 809-861.

SAMY, W., AND M. HASSANIAN. 2011. Paraoxonase-1 activity, malondialdehyde and glutathione peroxidase in non-alcoholic fatty liver disease and the effect of atorvastatin. Arab Journal of
Gastroenterology 12(2): 80-85.

SCHIFF, E. R., M. F. SORRELL, AND W. C. MADDREY. 2007. Schi-ff's diseases of the liver. 10th Ed. Philadelphia: Pa: Lippincott Williams \& Wilkins.

SCHMIDT, E., AND F.W. SCHMIDT. 1990. Progress in the enzyme diagnosis of liver disease; reality or illusion? Clinical Biochemistry 23:375-382.

SHETH, S. G., S. L. FLAMM, F. D. GORDON, AND S. CHOPRA. AST/ALT ratio predicts cirrhosis in patients with chronic hepatitis $\mathrm{C}$ virus infection. American Journal of Gastroenterology. 93 (1): 44-48.

SIAGRIS, D., M. CHRISTOFIDOU., G. J. THEOCHARIS, N. PAGONI, C. PAPADIMITRIOU, A. LEKKOU, K. THOMOPOULOS, I. STARAKIS, A. C. TSAMANDAS, C. LABROPOULOU-KARATZA. 2006. Serum lipid pattern in chronic hepatitis C: hstological and virological correlations. Journal of Viral Hepatitis 13(1):56-61.

Tilg, H. AND A. M. Diehl. 2000. Mechanisms of disease: cytokines in alcoholic and non-alcoholic steatohepatitis. N Engl J Med, 343. (20): 1467-1476.

WATSON, A. D., J. A. BERLINER, S. Y. HAMA, B. N. LA DU., K. F. FULL, A. M. FOGELMAN, AND M. NAVAB. 1995. Protective effect of high density lipoprotein associated paraoxonase-inhibition of the biological activity of minimally oxidized low-density lipoprotein. Journal of Clinical Investment 96(6): 2882-2891.

World Gastroenterology Organisation Global Guidelines (WGO). 2012. Nonalcoholic Fatty Liver Disease and Nonalcoholic Steatohepatitis WGO Global Guidelines NAFLD/NASH (long version).

YUI Y., T. AOYAMA, H. MORISHITA, M. TAKAHASHI, Y. TAKATSU, AND C. KAWAI. Serum prostacyclin stabilizing factor is identical to apolipoprotein A-I (Apo A-I). A novel function of Apo A-I. Journal of Clinical Investement 82 (3): 8037.

Received 9 September 2013

Accepted 28 October 2013 